\title{
SIX5 wt Allele
}

National Cancer Institute

\section{Source}

National Cancer Institute. SIX5 wt Allele. NCI Thesaurus. Code C111813.

Human SIX5 wild-type allele is located in the vicinity of 19q13.32 and is approximately $4 \mathrm{~kb}$ in length. This allele, which encodes homeobox protein SIX5, plays a role in both the regulation of transcription and the regulation of organogenesis. Mutations in this gene are associated with branchiootorenal syndrome type 2 . 